Geo-Marine Letters

Volume 26, Number 4 / September, 2006

http://dx.doi.org/10.1007/s00367-006-0032-4

(c)XXX Springer Science+Business Media
Archimer, archive institutionnelle de l'Ifremer http://www.ifremer.fr/docelec/

\title{
Eivissa slides, western Mediterranean Sea: morphology and processes
}

\author{
G. Lastras ${ }^{1}$, M. Canals ${ }^{1, *}$, D. Amblas ${ }^{1}$, M. Ivanov ${ }^{2}$, B. Dennielou ${ }^{3}$, L. Droz ${ }^{4}$, A. \\ Akhmetzhanov ${ }^{5}$ and TTR-14 Leg ${ }^{3}$ Shipboard Scientific Party
}

(1) GRC Geociències Marines, C/ Martí i Franquès s/n, Universitat de Barcelona, Barcelona, 08028, Spain

(2) UNESCO Centre of Marine Geology and Geophysics, Moscow State University, Moscow, 199899, Russia

(3) DRO/GM, IFREMER, B.P. 70, Plouzané, 29280, France

(4) Université de Bretagne Occidentale-CNRS, Plouzané, 29280, France

(5) National Oceanography Centre, Southampton, SO14-3ZH, UK

\author{
*: Corresponding author : M. Canals \\ Email: miquelcanals@ub.edu \\ Phone: +34-934021360 \\ Fax: $+34-934021340$
}

\begin{abstract}
:
After obtaining full-coverage swath bathymetry data in 1995 and very high-resolution acoustic profiles in 2002, four slides at the Balearic Margin of the Eivissa Channel in the western Mediterranean Sea were revisited in 2004 when side-scan sonar data were collected using a MAK-1M deep-towed acoustic system. These new findings, higher in resolution than those for the swath bathymetry, show two main features previously undetected within these submarine landslides: (1) a series of stepforming inclined and detached slabs oriented perpendicular to the slide movement and located in the uppermost part of the slides, and (2) arcuate regular positive ridges oriented also normal to the slide movement and located in the depositional lobes of some of the slides. The former are interpreted as extensional ridges, suggesting a retrogressive post-failure evolution of the slides. The latter are interpreted as compression ridges, related to plastic deformation of the sediment before movement freezing. Moreover, the new data show that fluid escape features are even more widespread in the Eivissa Channel than previously thought, dozens of new pockmarks less than $20 \mathrm{~m}$ in diameter having been identified.
\end{abstract}




\section{INTRODUCTION}

Submarine landslides are widespread on ocean margins all over the world, both glacial and river-dominated, and in volcanic archipelagos (Hampton et al. 1996; Canals et al. 2004). From a geological point of view, they are one of the most important processes in shaping continental margins, modifying the distribution pattern of canyon-channel systems and channel-levee complexes, and redistributing sediment from the shelf and upper slope to the base-of-slope and abyssal plains. Landslides pose a significant geologic risk, since they involve the release of large quantities of energy which can both directly and indirectly affect man-made structures. Direct impacts of submarine landslides on coastal structures, submarine power and telecommunication cables, pipelines, and oil platforms are associated with important economic losses (Campbell 1999). Moreover, the generation of tsunami waves due to fast mobilisation of rocks and sediments can, and has caused severe damage onshore (Tappin et al. 2001; Smith et al. 2004).

Consequently, major efforts have been made to study the occurrence, dynamics and impacts of seafloor failures, resulting in several overview publications in recent years (e.g., Locat and Mienert 2003; Mienert and Weaver 2003; Mienert 2004). Nevertheless, mass wasting processes are still poorly understood, mainly because the submarine environment is largely inaccessible, and their products occupy extensive areas which are difficult to cover in their entirety (cf. Haflidason et al. 2004). Therefore, investigations of small-scale submarine landslides, such as the $<0.2 \mathrm{~km}^{3}$ Afen Slide in the FaeroeShetland Channel (Wilson et al. 2004), are growing in importance. These, often displaying many of the characteristics of their larger counterparts, can be conveniently 
characterised in detail over their full extent, using different geophysical methods without extensive ship time needs.

This is the case for four small $\left(<0.4 \mathrm{~km}^{3}\right.$ and $\left.16 \mathrm{~km}^{2}\right)$ submarine landslides in the Eivissa Channel area, between the Iberian Peninsula and the Balearic Islands, western Mediterranean Sea (Fig. 1). These were first swath-mapped in 1995 and further surveyed in 2002 (Lastras et al. 2004). New high-resolution side-scan sonar data presented in this paper have been recently acquired (2004) with the aim of studying in higher detail the headwall scarps, with several detached and tilted slabs, and the depositional lobes, with compression ridges, of these slides.

\section{STUDY AREA}

\section{Geological Setting}

The Eivissa Channel, a slightly asymmetric, saddle-like north- to south-trending depression, separates La Nao Cape on the Iberian Peninsula, to the west, and the islands of Eivissa (Ibiza) and Formentera on the Balearic Promontory, to the east (Fig. 1). The channel represents the western end of this $348-\mathrm{km}$-long and $120-\mathrm{km}$-wide promontory, which consists of the Menorca, Mallorca and Eivissa structural blocks. Geologically, the Balearic Promontory is the prolongation of the external zone of the Betic Ranges from the Iberian Peninsula.

Three physiographic provinces can be distinguished within the Eivissa Channel: (1) the continental shelves off the town of Alacant to the west and the Eivissa-Formentera islands to the east, the shelf break being at around 100-130 m water depth; (2) the 
continental slopes down to $800 \mathrm{~m}$; and (3) a wide, smooth central depression locally exceeding $900 \mathrm{~m}$ in depth, which is interrupted by the prominent, $200-\mathrm{m}$-high east- to west-trending Xàbia Seamount (Lastras et al. 2004).

Following the southward-oriented regional circulation along the Iberian Peninsula eastern margins, most of the sediment reaching the Eivissa Channel is thought to come from rivers to the north on the Iberian Peninsula (mainly Ebre, Túria and Xúquer; Fig. 1). The Balearic continental shelf east of the channel is dominated by patches of benthic carbonate-dominated sedimentation (Canals and Ballesteros 1997). The Eivissa Channel plays a major role in the exchange of water masses between the South Balearic Basin to the south and the Valencia Trough to the north (Fig. 1). The interaction between northwards-oriented near-bottom currents and the Xàbia Seamount has formed a typical contouritic ridge and an associated depression (Faugères et al. 1999; Lastras et al. 2004).

Fluid escape features are present throughout the Balearic Promontory (Acosta et al. 2001), including in the Eivissa Channel (Lastras et al. 2004). Here, pockmarks have been identified to the north of the Xàbia Seamount, where their high abundance gives the seafloor an orange peel-like appearance, and on the Balearic continental slope where they are often aligned. In the latter region, pockmarks have been described as being similar in size, with diameters around $100 \mathrm{~m}$ and depths up to $15 \mathrm{~m}$, occurring at water depths of approx. $500 \mathrm{~m}$ (Lastras et al. 2004). 


\section{Previous work}

Four small slides are located on the Balearic continental slope of the Eivissa Channel, roughly aligned along the $0^{\circ} 48^{\prime} \mathrm{E}$ meridian, at water depths ranging between 600 and 900 m (Fig. 2a), namely (from south to north) the Ana, Joan, Nuna and Jersi slides (Lastras et al. 2004). Their areas range from 6.0 to $16.0 \mathrm{~km}^{2}$ and their volumes from 0.14 to $0.40 \mathrm{~km}^{3}$ (Table 1 ). They occur in segments of the continental slope where the slope varies from 1.6 to $3^{\circ}$. Their headwall scarps are as high as $50 \mathrm{~m}$ and display irregular, horseshoe-shaped morphologies (Fig. 2). Depositional lobes are characterized by areas of positive and rougher relief with respect to the surrounding seafloor. However, this relief is much less than the thickness of the disturbed sediment, demonstrating that sediments were not evacuated from the source area, with the partial exception of the Jersi Slide (Lastras et al. 2004).

Seismic facies observed in very high-resolution acoustic profiles vary both between the slides and also, depending on the section surveyed, within individual slides. For example, the Jersi Slide displays broken stratified facies locally at the foot of the headwall scarp and transparent seismic facies along the slide deposit, whereas the Ana Slide displays three successive seismic facies (transparent, stratified and chaotic) from the headwall to the toe (Lastras et al. 2004). These different seismic signatures between slides are probably due to variations in the degree of disintegration of the original stratification of the sediment. The slip plane of the four slides is one and the same characteristic high-amplitude reflector within the seismically well-stratified slope deposits outside the slides (Lastras et al. 2004). 


\section{MATERIALS AND METHODS}

Side-scan sonar data were collected with the MAK-1M system during the BALICAT survey onboard the R/V Professor Logachev in August 2004, part of the 14th campaign of the Training-Through-Research (TTR) program promoted by UNESCO in collaboration with Moscow State University.

The MAK-1M system is a deep-towed platform consisting of a $30-\mathrm{kHz}$ side-scan sonar, yielding a total swath range of up to $2 \mathrm{~km}$ when positioned about $100 \mathrm{~m}$ over the seafloor. Towing was at about 2.5 knot, resulting in a variable resolution of about 7 to 1 $\mathrm{m}$ across track and along track. In addition, the system incorporates a very highresolution acoustic profiler operating at $5 \mathrm{kHz}$. Position was by means of a shortbaseline underwater navigation system. Vessel positioning was by means of an Ashtech GG24 GPS and a GLONASS receiver.

In the BALICAT survey area, side-scan sonar data cover $115 \mathrm{~km}^{2}$, and about $65 \mathrm{~km}$ of sub-bottom profiles were collected (Fig. 2) between $38^{\circ} 37^{\prime}$ and $38^{\circ} 50^{\prime} \mathrm{N}$ and between $0^{\circ} 45^{\prime}$ and $0^{\circ} 51^{\prime} \mathrm{E}$. Onboard processing included slant-range correction of the sonographs, geometrical vertical correction of the sub-bottom profiles for the recovery of actual seafloor topography, and smoothing-average filtering of both types of record.

Ship track planning was based on data obtained onboard the R/V Hespérides in 1995 (BIG'95 survey) and 2002 (MARINADA survey), when 2,287 km² of Simrad EM-12S swath bathymetry data and $642 \mathrm{~km}$ of hull-mounted Simrad topographic parametric source TOPAS PS 018 very high-resolution acoustic profiles were obtained (Fig. 2a; Lastras et al. 2004). This swath bathymetry data have a horizontal resolution of $\sim 35 \mathrm{~m}$ 
at $\sim 800$ m water depth (0.043 times the depth; Simrad Subsea 1991). Because MAK-1M has a variable resolution of about 7 to $1 \mathrm{~m}$ across track and along track, most shadows observed in MAK-1M sonographs represent previously undetected features on the seafloor with the swath bathymetry.

\section{RESULTS}

\section{Side-scan sonar}

Three MAK-1M side-scan sonar lines completely cover the extent of the Ana and Jersi slides, and partially that of the Nuna and Joan slides (Fig. 2a). The slide deposits do not show a clearly contrasting backscatter compared with that of to the rest of the Balearic Margin of the Eivissa Channel, probably due to the presence of a thin regional sediment drape. Thus, changes in seafloor response are mainly due to the angle of insonification and, particularly, to shadows cast by positive relief.

In the Ana (Fig. 3), Joan (Fig. 2), Nuna (Fig. 4) and Jersi (Fig. 5) slides, the headwall scarps and sidewalls display sinuous morphologies, and they often look discontinuous, as if they were made of several, shorter scarp sections. The slide masses show, in their upper sections, i.e. close to the headwall scarps, many step-forming detached and tilted sediment slabs, giving a general staircase-like pattern. These slightly curved steps are generally up to $100 \mathrm{~m}$ long and $40 \mathrm{~m}$ wide, and are oriented perpendicular to the direction of slide motion (e.g., Fig. 4). In the uppermost part of the Jersi Slide, however, they are continuous from one edge of the slide to the other and attain lengths of up to $300 \mathrm{~m}$ (Fig. 5). Further downslope from the headwall scarp, steps are more 
discontinuous and degraded, their across-slide length decreasing but generally not their width (Figs. 4 and 5).

Strikingly, the MAK-1M side-scan sonographs show that the depositional lobes of at least the Ana and Nuna slides (Fig. 6), which display chaotic seismic facies in very high-resolution acoustic profiles (Lastras et al. 2004) and are featureless in swath bathymetry maps (Fig. 2), have numerous arcuate ridges oriented normal to the direction of slide movement. These ridges are up to $800 \mathrm{~m}$ long and $\sim 20 \mathrm{~m}$ in wave length, and have a much smoother relief than the step-forming slabs in the upper slide sections. The Joan Slide depositional lobe is not covered by the side-scan data (Fig. 2a), and the Jersi Slide depositional lobe, which is entirely made of transparent seismic facies, is featureless in the side-scan sonar images.

New data demonstrate that previously undescribed $<40 \mathrm{~m}$ in diameter pockmarks are widespread in the Balearic margin of the Eivissa Channel (Figs. 3 to 5). These were not detected before due to the lower resolution of the EM-12S swath bathymetry available. They are located at greater water depths and are smaller in size than pockmarks observed in previous cruises (Lastras et al. 2004)

\section{Acoustic profiles}

Acoustic profiles $(5 \mathrm{kHz})$, obtained by means of the MAK-1M acoustic system, show almost no penetration into the sediment in some sections of the slides. Where subseafloor reflectors can be observed, these are faint and difficult to follow. Nonetheless, the prominent slip plane (SP) reflector described by Lastras et al. (2004) was recorded below the Nuna (Fig. 4) and Jersi slides (Fig. 5). 
The acoustic profiles show the different morphological character of the smooth, undisturbed sections of the Balearic Margin, and the irregular negative relief of the headwall scarp areas (Figs. 3 and 5) and the positive relief of the depositional lobes (Figs. 5 and 6). In addition, the profiles reveal the presence of small pockmarks (less than $2 \mathrm{~m}$ in depth; Fig. 5) surrounding all the slides. These had previously not been detected on the swath bathymetry records.

\section{DISCUSSION}

Headwall scarps and structures in the upper part of slide masses are one of the features better imaged by MAK-1M side-scan sonar, and this is also the case for the four slides in the Eivissa Channel. The staircase geometry of the headwall scarp has been observed at a much larger scale, but also on sonographs, in the BIG'95 debris flow in the Ebre margin, north of the study area (Lastras et al. 2003), and in the Storegga Slide in the Norwegian margin (Haflidason et al. 2003). Lindberg et al. (2004) described similar features in the Nyk Slide, a partly buried slide offshore northern Norway, and related these to extensional ridges formed as sediments moved downslope driven by gravity. These extensional ridges are commonly observed in the upper area of slides which are not fully evacuated (Prior et al. 1984), and consist of material which was not completely disintegrated before movement stopped. This is also the case of the Eivissa slides (Lastras et al. 2004).

Lindberg et al. (2004) pose the question as to whether these structures are developed by upslope retrogression of the headwall scarp or not. Although many factors are important 
in controlling the initiation point of a slide, such as zones of fluid escape, underlying structural controls and sedimentation rates, we consider these factors to be uniform or constant in slides as small as those in the Eivissa Channel. Thus, initiation should take place in areas with maximum gradients. However, the location of the headwall scarp is not coincident with the maximum gradient, located some hundreds of meters downslope. Therefore, we consider that the Eivissa Channel slides are retrogressive, and that the edge-to-edge, crescent-shaped detached and tilted slabs in the uppermost part of the Jersi Slide represent the last stages of retrogression. The initial slide scarp would be located in the area of maximum slope (Fig. 7, schema A) as would be expected from simple failure dynamics, and would retrograde (Fig. 7, schema B) when upslope sediments become unstable due to a lack of support. Each retrogression stage would create a series of steps, some of which could remain more or less intact within the slide mass, as seen, for example, in an acoustic profile across the Ana Slide (Fig. 4 in Lastras et al. 2004). Since the slope angle decreases upslope, retrogression would cease when the driving force is not large enough to mobilize sediment, even if sediment partially lacks downslope support (Fig. 7, schema C). During retrogression, some of the pockmarks could be erased or their walls could become part of some scarps (Fig. 7, schema C), as suggested by Lastras et al. (2004) for the Ana Slide.

Positive relief features perpendicular to the sliding direction observed in the depositional lobes of the Ana and Nuna slides have also been described before in other submarine slides, and are interpreted as compression ridges resulting from plastic deformation, similarly to those observed in the Nyk Slide (Lindberg et al. 2004), which are typically found at the toe (i.e. in the most distal parts) of slides and debris flows (Prior et al. 1984). Coincidently, the Ana and Nuna slides both display chaotic facies 
with internal reflections, whereas the Jersi Slide, which has no compression ridges, displays totally transparent facies. The absence of compression ridges in the Jersi Slide could be indicative of a higher degree of disruption of the material, which could have become less plastic and closer to the liquid limit after failure. Seeing that the granulometry, water content and, in general, the characteristics of the sediments should be essentially the same for all of these slides (cf. Lastras et al. 2004), this higher disintegration of the internal structure could be related to a longer run-out distance $(\sim 3$ km, Fig. 7 in Lastras et al. 2004), in contrast to the modest run-out of the other slides (i.e. less than $1 \mathrm{~km}$, Fig 4. in Lastras et al. 2004). Note also that the distance between the area of maximum slope and the headwall scarp in the Jersi Slide is much longer (Fig. 2; Fig. 7 in Lastras et al. 2004).

These features are indicative of different stages of sediment disruption during landslide evolution. A first stage would involve the breakage, tilting and detachment of sediment slabs from the headwall scarp, above a certain slip plane, in this particular case the SP reflector (Lastras et al. 2004). Initially, these would preserve internal stratification, and thus would display stratified seismic facies similar to so-called rotated blocks within the Ana Slide (Fig. 4 in Lastras et al. 2004). Retrogression pulses would form a series of these sediment slabs, creating the steps in the upper part of the slides (Fig. 7, schema B). A second stage would be linked to initial liquefaction and partial flowage of the sediment, involving plastic deformation and the disruption of internal stratification. This would produce compression ridges in the seafloor, yielding discontinuously stratified or chaotic seismic facies within the slide mass, as seen at the toe of the Ana and Nuna slides (Fig. 6; Figs. 4 and 6 in Lastras et al. 2004). The Jersi Slide, with a longer run- 
out, evolved in to the final disruption stage, related to total liquefaction of the sediment and yielding a deposit of transparent seismic facies (Fig. 7 in Lastras et al. 2004).

Last but not least, the widespread presence of pockmarks in the Eivissa Channel is clearly indicative that escapement of fluids from the sediment is a highly significant process on these slopes, and most probably heavily related to instability of shallow sediment.

\section{CONCLUSIONS}

MAK-1M side-scan sonar data show new features within four submarine landslides previously described in the Eivissa Channel based on swath bathymetry and highresolution seismic profiles. Step-forming detached and tilted slabs located in the uppermost part of the slides, and arcuate regular positive ridges in the depositional lobes of some of the slides, are interpreted as extensional ridges formed during retrogression of the headwall scarps upslope of the maximum gradient, and as compression ridges related to plastic deformation of the sediment during movement, respectively. The observation of these features, described earlier in both smaller and larger submarine landslides around the world, have important implications in the study of the post-failure dynamics of these four small slides, since they are indicative of different stages of sediment disruption.

Furthermore, these data demonstrate that the study of small-scale landslides, which requires less ship time and, in general, lower effort, can help in the understanding of large-scale, margin-wide mass wasting processes. 


\section{ACKNOWLEDGEMENTS}

This research was supported by the HERMES project, EC contract no. GOCE-CT-2005511234, funded by the European Commission's Sixth Framework Programme under the priority Sustainable Development, Global Change and Ecosystems, by the projects SPACOMA (01-LEC-EMA14F) and WEST-MED (01-LEC-EMA22F) of the EUROCORES Program on EUROMARGINS of the European Science Foundation, the EURODOM Research Training Network (HPRN-CT-2002-00212) and the VFP project EUROSTRATAFORM (EVK3-2002-00079) of the European Community, and by the Generalitat de Catalunya Grups de Recerca Consolidats grant 2001 SGR-00076. The authors would like to thank the suggestions made by two anonymous reviewers and the Editor which greatly helped to improve this paper. The TTR-14 Leg 3 Shipboard Scientific Party also included E. Bileva, V. Blinova, C. Brönnimann, V. Catterall, K. Chumakova, S. Costa, D. Daudin, P. Ferrer, P. Golynchik, I. Gyr'ev, V. Kiselev, D. Korost, E. Kozlova, E. Logvina, V. Malin, A. Micallef, V. Osokin, A. Ovsjannikov, E. Sarantsev, A. Shoronova, A. Shuvalov, A. Sungurov, V. Tarasov, D. Titkova, O. Vidal and A. Zotova. The publication reflects only the views of the authors; the EC is not liable for any use which may be made of this paper. 


\section{REFERENCES}

Acosta J, Muñoz A, Herranz P, Palomo C, Ballesteros M, Vaquero M, Uchupi E (2001)

Pockmarks in the Ibiza Channel and western end of the Balearic Promontory (western Mediterranean) revealed by multibeam mapping. Geo-Mar Lett 21:123-130

Campbell KJ (1999) Deepwater geohazards: how significant are they? Leading Edge $18: 514-519$

Canals M, Ballesteros E (1997) Production of carbonate particles by phytobenthic communities on the Mallorca-Menorca Shelf, northwestern Mediterranean Sea. DeepSea Res II 44:611-629

Canals M, Lastras G, Urgeles R, Casamor JL, Mienert J, Cattaneo A, De Batist M, Haflidason H, Imbo Y, Laberg JS, Locat J, Long D, Longva O, Masson DG, Sultan N, Trincardi F, Bryn P (2004) Slope failure dynamics and impacts from seafloor and shallow sub-seafloor geophysical data: case studies from the COSTA project. Mar Geol 213:9-72

Faugères JC, Stow DAV, Imbert P, Viana A (1999) Seismic features diagnostic of contourite drifts. Mar Geol 162:1-38

Haflidason H, Sejrup HP, Berstad IM, Nygård A, Richter T, Bryn P, Lien R, Berg K (2003) A weak layer feature on the Northern Storegga Slide escarpment. In: Mienert J, Weaver PPE (eds) European Margin sediment dynamics: side-scan sonar and seismic images. Springer, Berlin Heidelberg New York, pp 55-62 
Haflidason H, Sejrup HP, Nygård A, Mienert J, Bryn P, Lien R, Forsberg CF, Berg K, Masson D (2004) The Storegga Slide: architecture, geometry and slide development. Mar Geol 213:201-234

Hampton MA, Lee JL, Locat J (1996) Submarine landslides. Rev Geophys 34:33-59

Lastras G, Canals M, Urgeles R (2003) Lessons from sea-floor and subsea-floor imagery of the BIG'95 debris flow scar and deposit. In: Locat J, Mienert J (eds) Submarine mass movements and their consequences. Kluwer, Dordrecht, pp 425-431

Lastras G, Canals M, Urgeles R, Hughes-Clarke JE, Acosta J (2004) Shallow slides and pockmark swarms in the Eivissa Channel, western Mediterranean Sea. Sedimentol $51: 837-850$

Lindberg B, Laberg JS, Vorren TO (2004) The Nyk Slide - morphology, progression, and age of a partly buried submarine slide offshore northern Norway. Mar Geol 213:277-289

Locat J, Mienert J (eds) (2003) Submarine mass movements and their consequences. Kluwer, Dordrecht

Mienert J (ed) (2004) COSTA - continental slope stability: major aims and topics. Mar Geol 213:1-7 
Mienert J, Weaver PPE (eds) (2003) European margin sediment dynamics: side-scan sonar and seismic images. Springer, Berlin Heidelberg New York

Prior DB, Bornhold BD, Johns MW (1984) Depositional characteristics of a submarine debris flow. J Geol 92:707-727

Simrad Subsea (1991) Product description. Simrad EM 12 multibeam echosounder. Simrad Subsea, Horten, Norway

Smith WHF, Sandwell DT (1997) Global seafloor topography from satellite altimetry and ship depth soundings. Science 277:1957-1962

Smith DE, Shi S, Cullingford RA, Dawson AG, Dawson S, Firth CR, Foster IDL, Fretwell PT, Haggart BA, Holloway LK, Long D (2004) The Holocene Storegga Slide tsunami in the United Kingdom. Quat Sci Rev 23:2291-2321

Tappin DR, Watts P, McMurtry GN, Lafoy Y, Matsumoto T (2001) The Sissano, Papua New Guinea tsunami of July 1998 - offshore evidence on the source mechanism. Mar Geol 175:1-23

Wilson CK, Long D, Bulat J (2004) The morphology, setting and processes of the Afen Slide. Mar Geol 213:149-167 
Fig. 1 Bathymetric map of the Balearic Promontory region in the western Mediterranean Sea (see inset; extracted from Smith and Sandwell 1997). Contours are at $100,200,500,750,1,000,1,500,2,000$ and 2,500 m. Black box shows location of the study area (cf. Fig. 2). The arrows on the coast mark the location of discharge from the Ebre, Túria and Xúquer rivers. Note that the Eivissa is the deepest channel connecting the València Trough and the South Balearic Basin

Fig. 2a Swath bathymetry map of the study area, showing the location of very highresolution seismic reflection profiles acquired in 2002 and MAK-1M side-scan sonar lines obtained in 2004. Contours are every $5 \mathrm{~m}$. b Shaded relief image of the study area, illuminated from the north. From south to north, slides are named Ana Slide (AS), Joan Slide (JoS), Nuna Slide (NS) and Jersi Slide (JeS). Colours correspond to shallowest (reddish) to deepest (bluish) water depths. c MAK-1M side-scan sonar mosaic of the study area. Contours are every $25 \mathrm{~m}$. Limits of the slide deposits (dotted lines) and the headwall scarps (continuous lines) are shown in a to c

Fig. 3a MAK-1M sonograph across the Ana Slide headwall scarp showing steps, interpreted as extensional ridges within the slide mass, and small pockmarks. Interpretation of the sonograph is also provided. Note that the sonograph is in inverted grey-scale (i.e. illuminated areas are dark grey, and shadowed areas are light grey). b Acoustic profile $(5 \mathrm{kHz})$ along the fish track and $\mathbf{c}$ TOPAS acoustic profile from the MARINADA cruise (see dotted lines B and $\mathrm{C}$ in the sonograph for location), showing the step-forming slabs and the variations in the acoustic facies within the slide and the basal reflector that acted as slip plane (SP). Location in Fig. 2 
Fig. 4a MAK-1M sonograph across the Nuna Slide headwall scarp and b $5-\mathrm{kHz}$ acoustic profile along the fish track, showing steps, interpreted as extensional ridges within the slide mass, a large pockmark very close to the headwall, corresponding to that described by Lastras et al. (2004), and the basal reflector that acted as slip plane (SP). Interpretation of the sonograph is also provided. Note that the sonograph is in inverted grey-scale. Location in Fig. 2

Fig. 5a MAK-1M sonograph mosaic across the Jersi Slide sidewall and b $5-\mathrm{kHz}$ acoustic profile along the fish track, showing steps, interpreted as extensional ridges within the slide mass, several small pockmarks, and the basal reflector that acted as slip plane (SP). Interpretation of the sonograph is also provided. Note that the sonograph is in inverted grey-scale. In a, black arrows show the insonification direction. Location in Fig. 2

Fig. 6a MAK-1M sonograph across the Nuna Slide depositional lobes, showing several compression ridges. Note that the sonograph is in inverted grey-scale. b Acoustic profile $(5 \mathrm{kHz})$ along the fish track and $\mathbf{c}$ TOPAS acoustic profile from the MARINADA cruise (see dotted line B in the sonograph for location), showing chaotic acoustic facies within the slide lobes and the basal reflector that acted as slip plane (SP). Location in Fig. 2

Fig. 7 Interpreted development of the Eivissa Channel slides, showing the formation of the extensional ridges close to the headwall scarp and of the compression ridges in the depositional lobe. Note that the distance from headwall to toe (a) is much longer than the run-out distance (the distance of the centre of masses before and after the slide) (b) 
Table 1 General characteristics of the four slides in the Eivissa Channel

\begin{tabular}{|c|c|c|c|c|c|c|c|c|c|}
\hline \multirow{2}{*}{$\begin{array}{l}\text { Slide } \\
\text { name }\end{array}$} & \multicolumn{2}{|c|}{ Location } & \multirow{2}{*}{$\begin{array}{l}\text { Water } \\
\text { depth } \\
(\mathrm{m})\end{array}$} & \multirow{2}{*}{$\begin{array}{c}\text { Slope } \\
\text { angle } \\
\left({ }^{\circ}\right)\end{array}$} & \multirow{2}{*}{$\begin{array}{l}\text { Scarp } \\
\text { height } \\
\text { (m) }\end{array}$} & \multirow{2}{*}{$\begin{array}{l}\text { Maximum } \\
\text { thickness } \\
\text { (m) }\end{array}$} & \multirow{2}{*}{$\begin{array}{l}\text { Run-out }^{\mathrm{a}} \\
\quad(\mathrm{km})\end{array}$} & \multirow{2}{*}{$\begin{array}{l}\text { Area } \\
\left(\mathrm{km}^{2}\right)\end{array}$} & \multirow{2}{*}{$\begin{array}{c}\text { Volume } \\
\left(\mathrm{km}^{3}\right)\end{array}$} \\
\hline & North & East & & & & & & & \\
\hline Ana & $38^{\circ} 38^{\prime} 30^{\prime \prime}$ & $0^{\circ} 49^{\prime} 00^{\prime \prime}$ & $635-815$ & 1.6 & 30 & 44 & $<1$ & 6.0 & 0.14 \\
\hline Joan & $38^{\circ} 41^{\prime} 00^{\prime \prime}$ & $0^{\circ} 47^{\prime} 30^{\prime \prime}$ & $600-870$ & 2.5 & 20 & $>25$ & $?$ & 16.0 & 0.40 \\
\hline Nuna & $38^{\circ} 43^{\prime} 15^{\prime \prime}$ & $0^{\circ} 47^{\prime} 30^{\prime \prime}$ & $675-860$ & 3.0 & 50 & 50 & $<1$ & 10.3 & 0.31 \\
\hline Jersi & $38^{\circ} 47^{\prime} 30^{\prime \prime}$ & $0^{\circ} 47^{\prime} 15^{\prime \prime}$ & $755-905$ & 1.9 & 15 & 45 & $\sim 3$ & 7.9 & 0.19 \\
\hline
\end{tabular}

${ }^{a}$ Run-out values correspond to rough approximations of the actual travel distance of the centre of masses of each landslide, rather than the length of the slide from headwall to toe (Fig. 7) 
Fig. 1

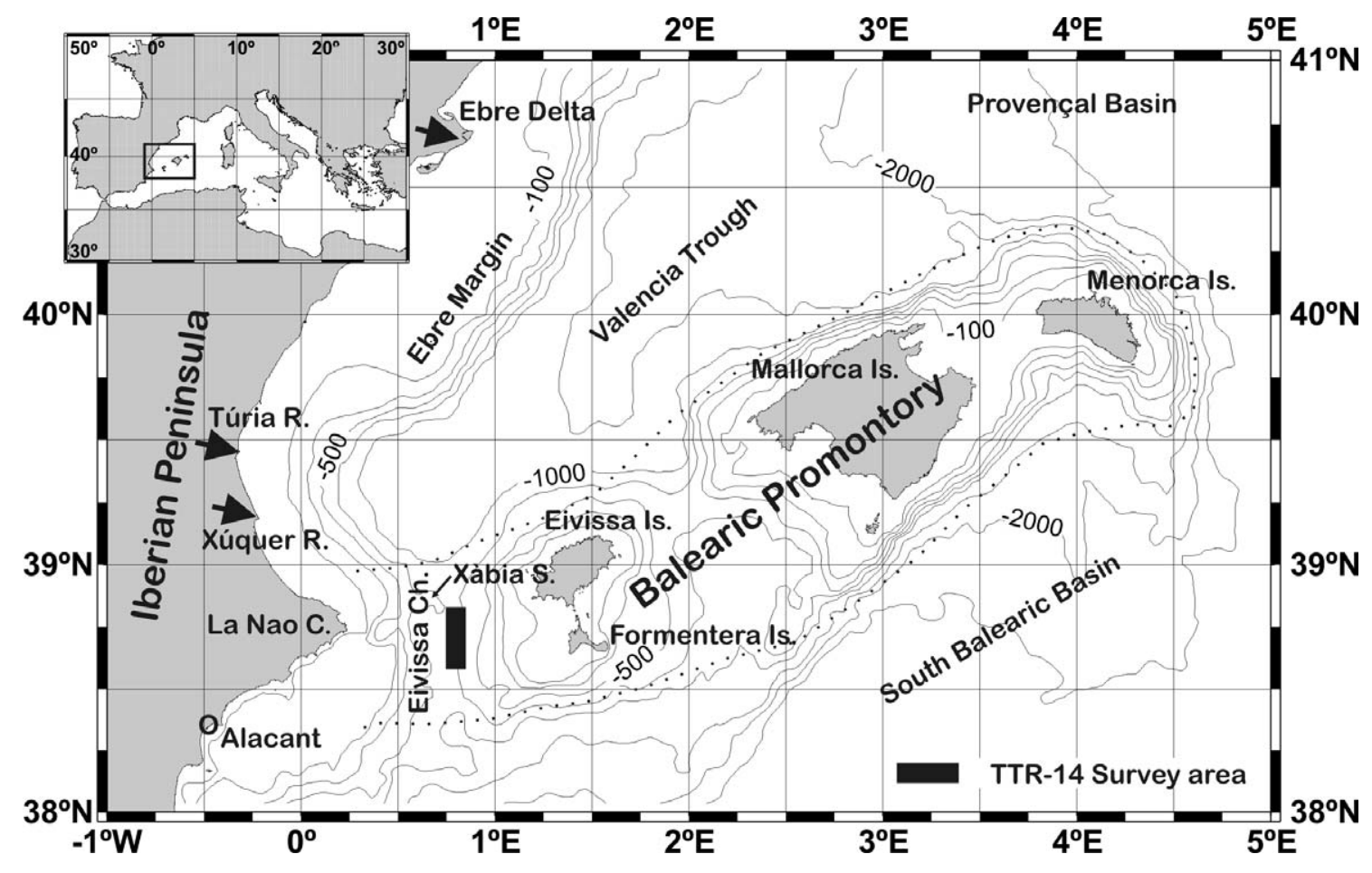


Fig. 2

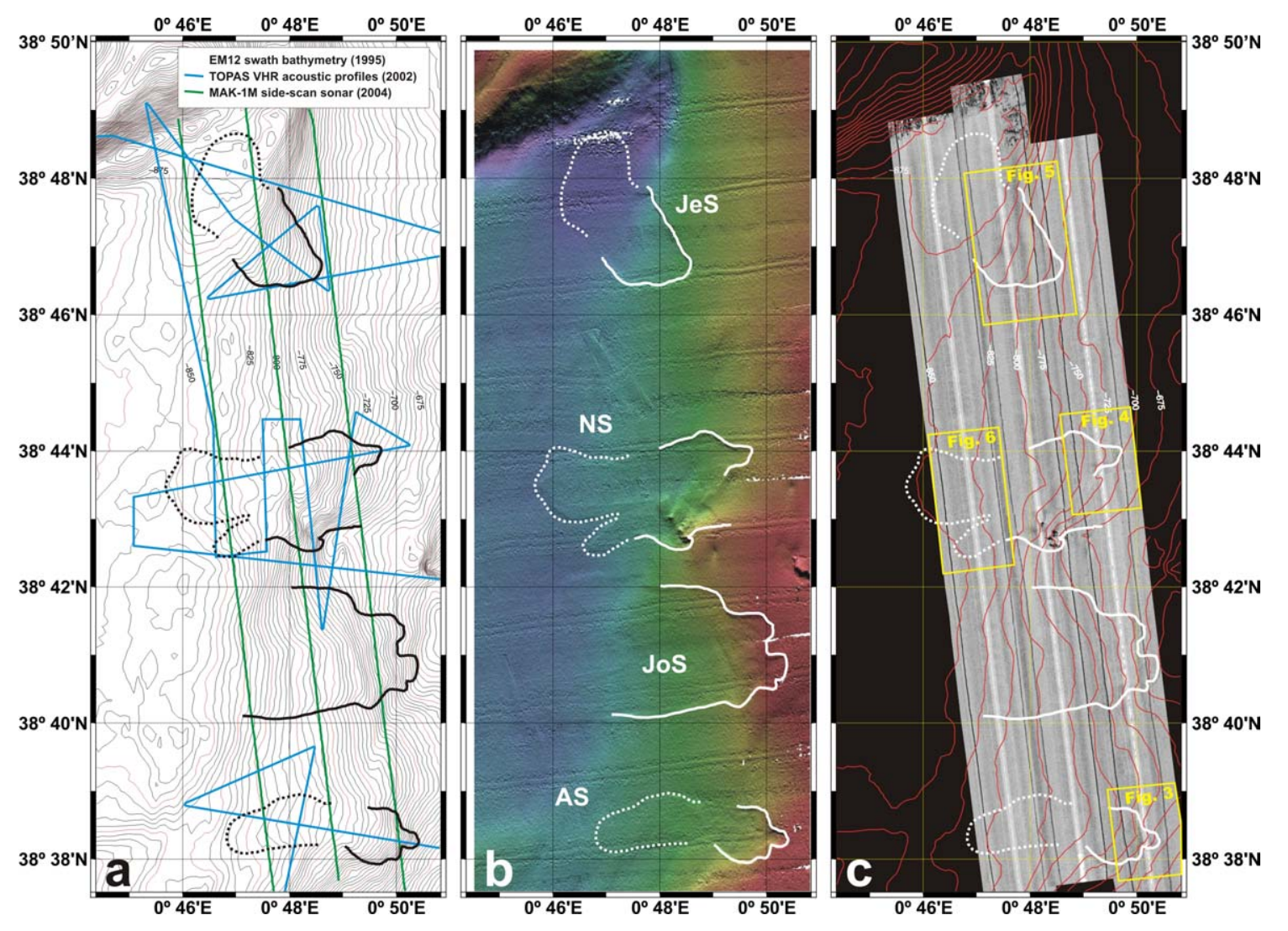


Fig. 3

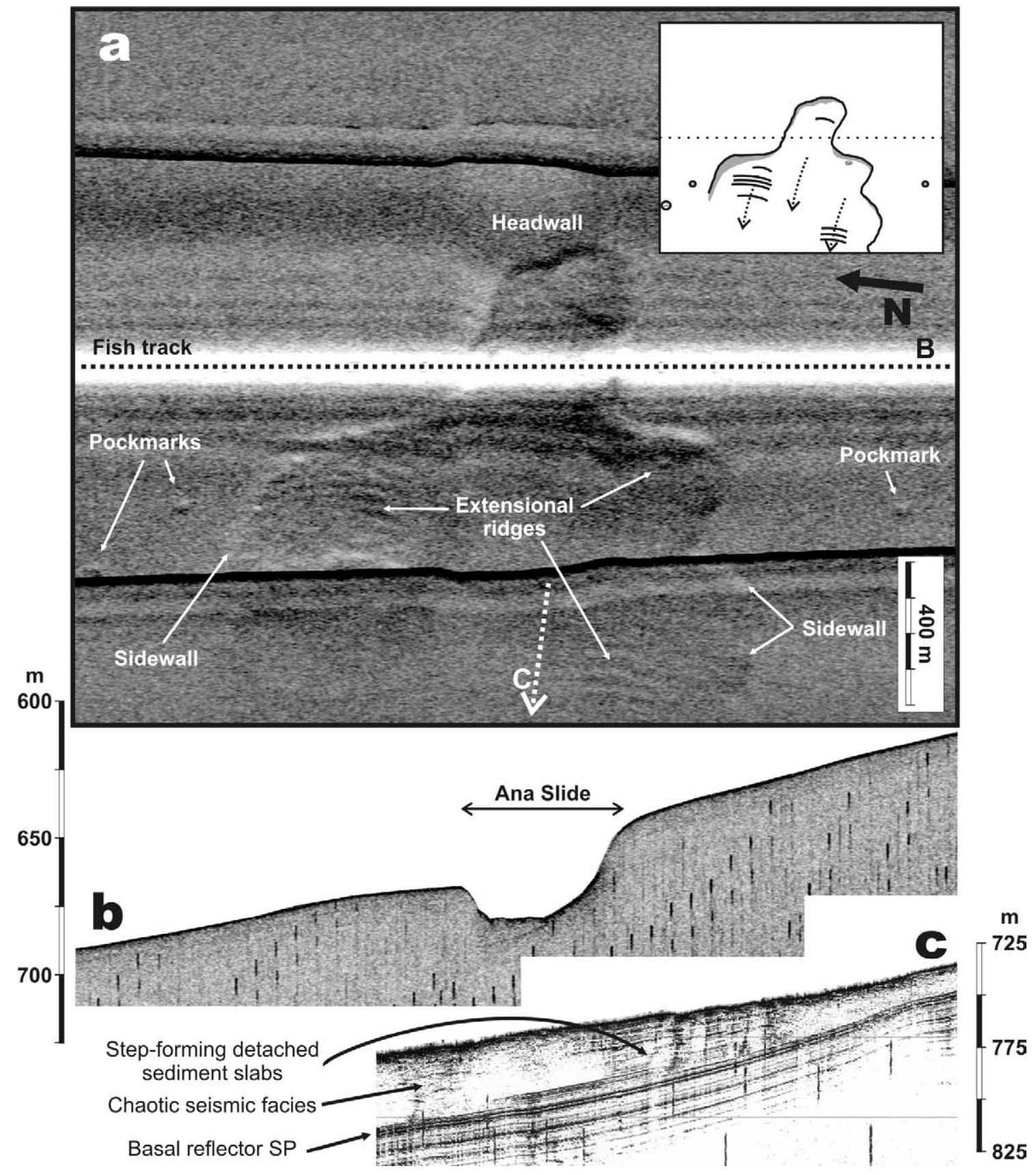


Fig. 4

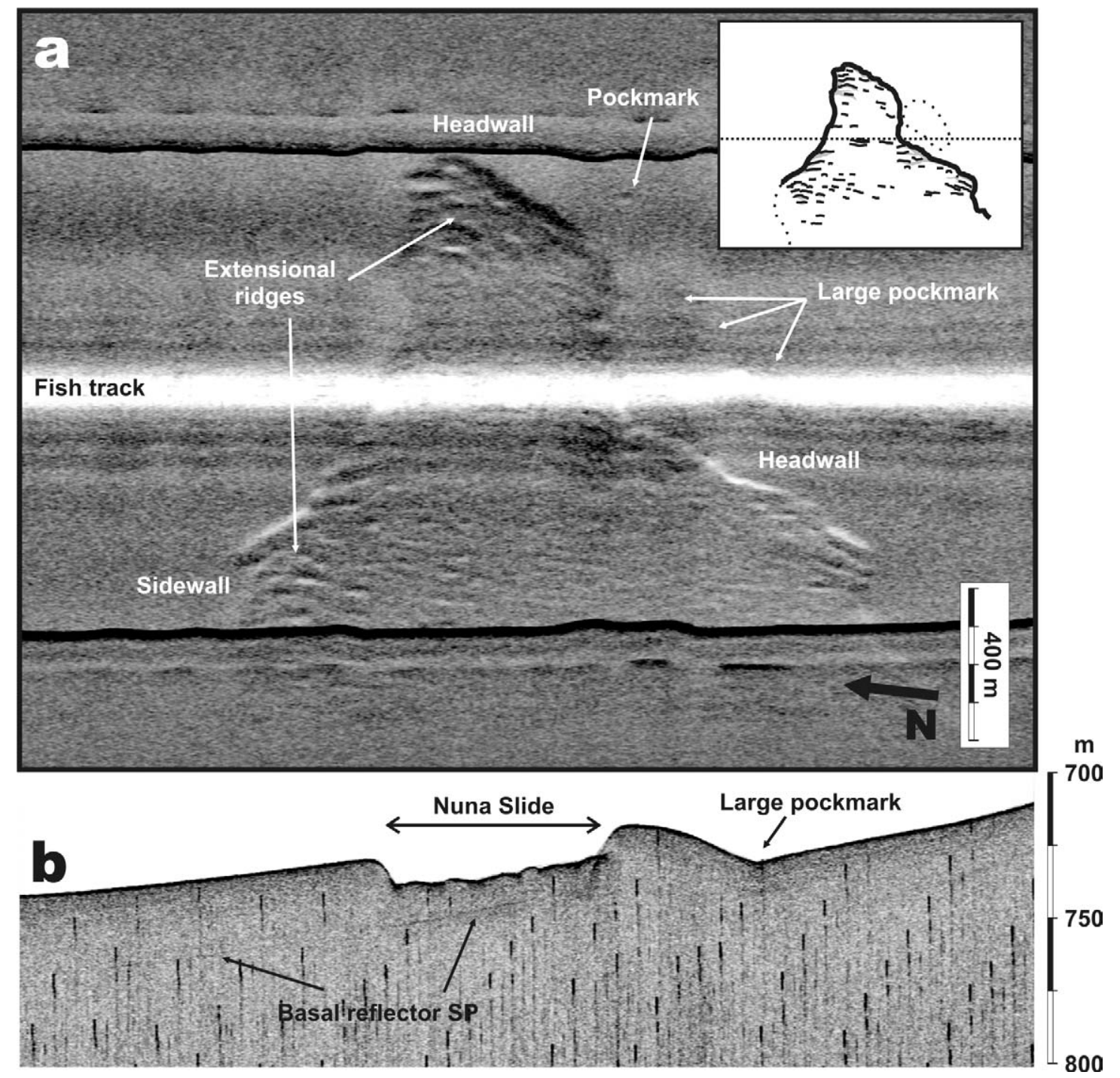


Fig. 5

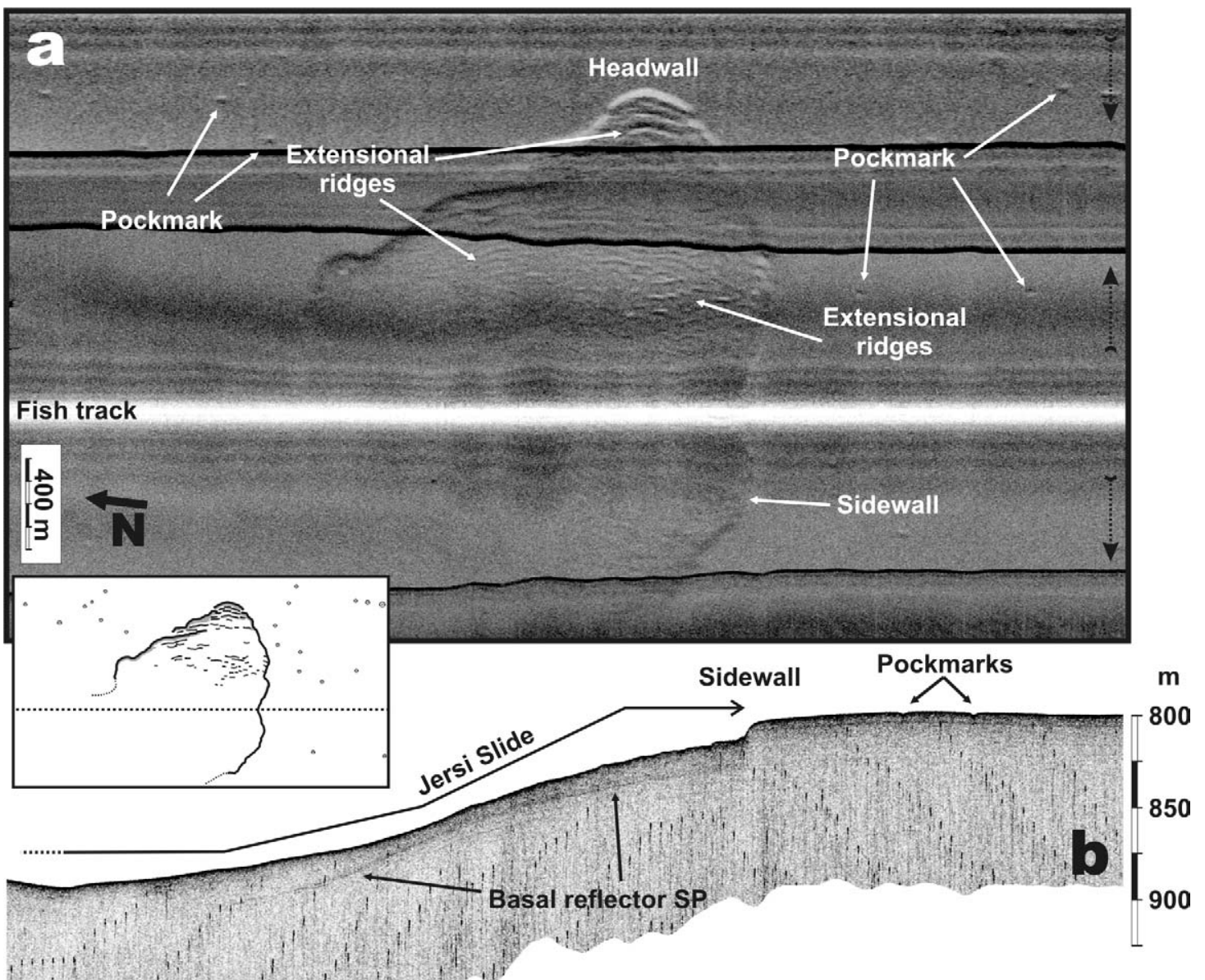


Fig. 6

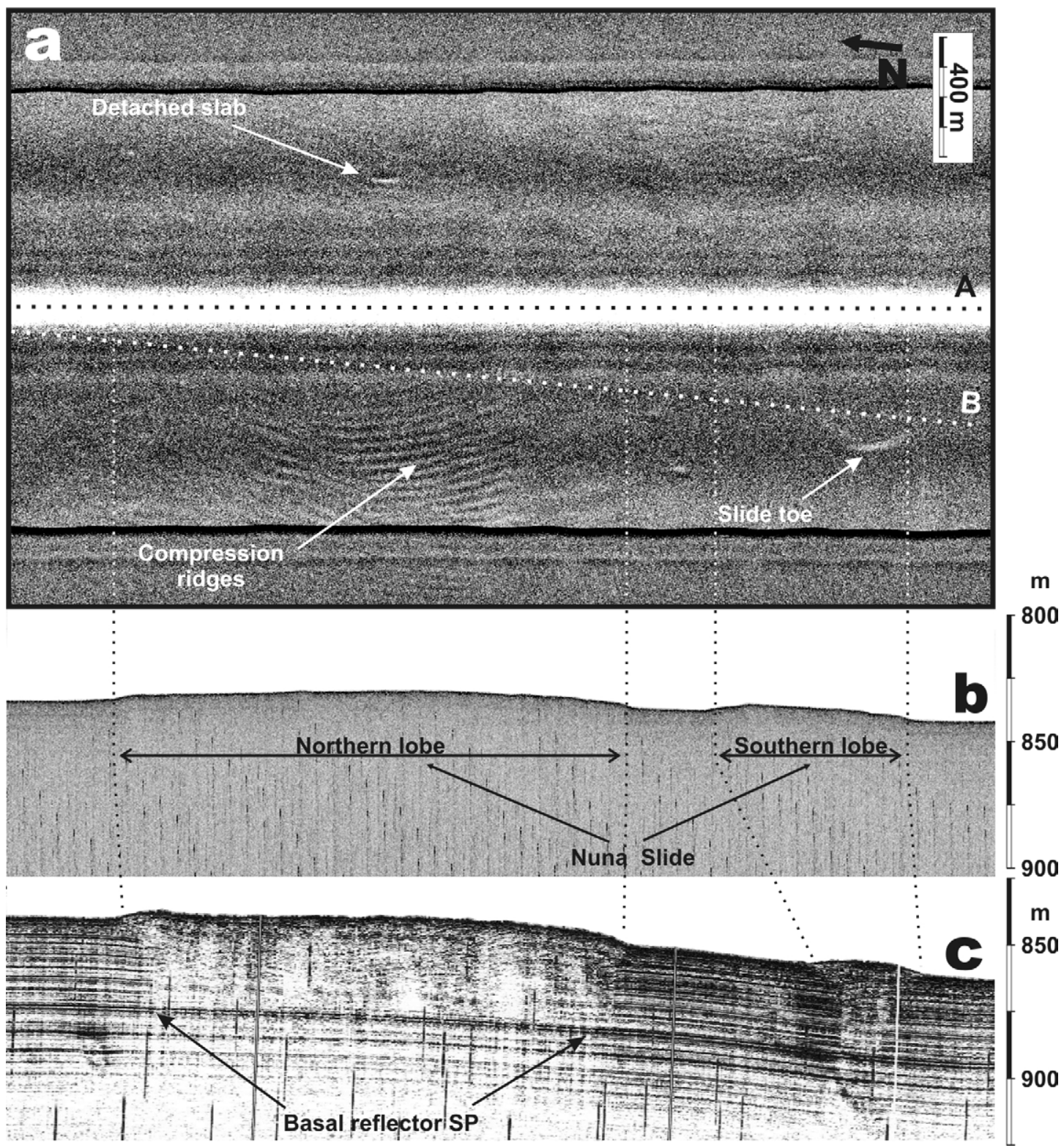


Fig. 7

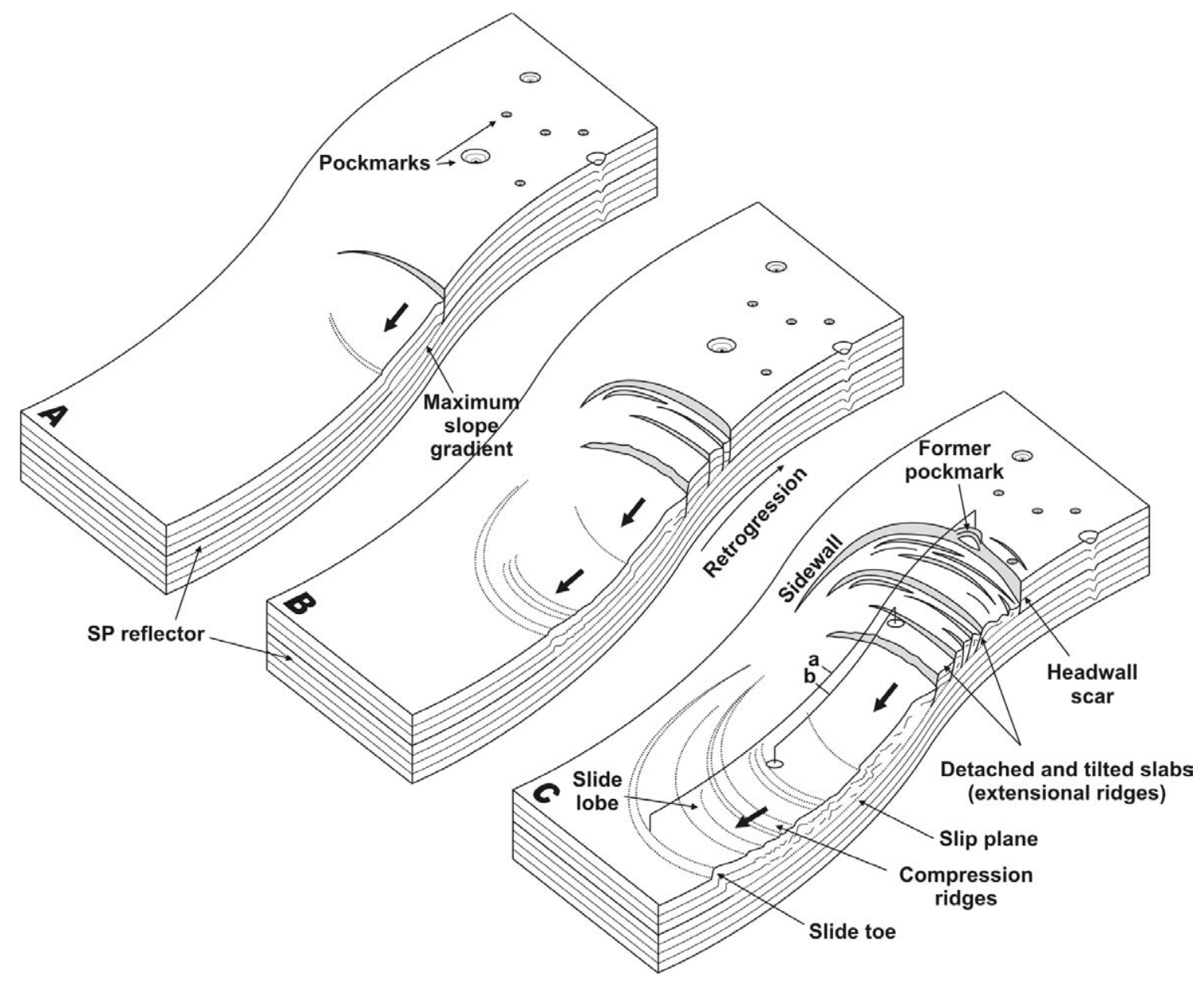

